\title{
Vaccination status (PCV13) of children with pneumococcal meningitis
}

\author{
Aliya Seidullayeva ${ }^{1,2}$, Dinagul Bayesheva ${ }^{1,2}$, Bayan Turdalina ${ }^{1,2}$, Alyona Altynbekova ${ }^{1,2}$, Aliya Omarova ${ }^{1,2}$, \\ Meruert Khamitova $^{1,2}$, Sabit Tashenov ${ }^{1,2}$, Aislu Otarbayeva ${ }^{1,2}$, Samat Kozhakhmetov ${ }^{3}$
}

${ }^{1}$ Department of Pediatric Infectious Diseases, Astana Medical University, Nur-Sultan city, Republic of Kazakhstan

${ }^{2}$ Department of Pediatric Infectious Diseases, №3 Multidisciplinary City Children's Hospital, Nur-Sultan city, Republic of Kazakhstan

"National Laboratory Astana" Life Sciences Center, Nazarbayev University, Nur-Sultan city, Republic of Kazakhstan

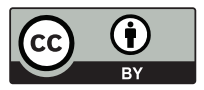
International License

Received: 2020-04-08

Accepted: 2020-04-27

UDC: 618.1

J Clin Med Kaz 2020; 2(56):46-49

Corresponding Author: Aliya Seidullayeva, $\mathrm{PhD}$ teaching assistant, Department of Pediatric Infectious Diseases, Astana Medical University. Address: 51a, Beibitshilik Street, Nur-Sultan city, Republic of Kazakhstan. Tel.: 87011860303

E-mail: seidullayeva.aliya@gmail.com

\section{Abstract}

Pneumococcal meningitis in children is one of the reasons for the development of serious neurological complications. According to various authors, in developed countries, the incidence rate ranges from 8 to 34 cases per 100,000 population, in Kazakhstan there is no etiological interpretation of bacterial meningitis, and therefore there are no official statistics on the incidence. To date, in more than 120 countries, the pneumococcal conjugate vaccine has been added to the vaccination calendar, which is the most effective method for reducing the incidence of bacterial meningitis pneumococcal etiology. This article reflects the effectiveness of vaccination and the risk of bacterial meningitis in children with pneumococcal meningitis in terms of using the PCV13 vaccine.

Keywords: pneumococcal meningitis, vaccination, PVC13, children

\section{ПНЕВМОКОКТІ МЕНИНГИТІ БАР БАЛАЛАРДЫН ВАКЦИНАЦИЯЛЫҚ СТАТУСЫ (ПКВ13)}

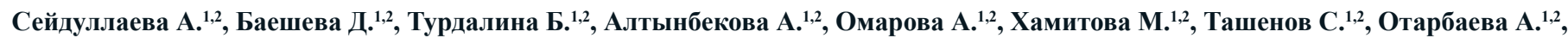
Кожахметов $\mathrm{C}^{3}$

'Балалар инфекциялық аурулар бөлімшесі, Астана медицина университеті, Нұр-Сұлтан қаласы, Қазақстан Республикасы

${ }^{2}$ Балалар инфекциялық аурулар бөлімшесі, №3 Көпбейінді қалалық балалар ауруханасы, Нұр-Сұлтан қаласы, Қазақстан Республикасы

${ }^{3}$ Өмір туралы ғылымдар орталығы «National Laboratory Astana», Назарбаев Университеті, Нұр-Сұлтан қаласы, Қазақстан Республикасы

\section{ТҰЖЫРЫМДАМА}

Балалардағы пневмококты менингит - бұл ауыр неврологиялық асқынулар дамуының бір себебі болып табылады. Көптеген авторлардың мәліметі бойынша, дамыған елдердерде ауру жиілігі 100000 тұрғынға 8-ден 34 жағдайға дейінгі аралықта, ал Қазақстанда бактериялық менингиттердің этиологиялық құрылымы жоқ, осыған байланысты инвазивті пневмококтің аурулардың аурушаңдылық деңгейі жөнінде ресми мәлімет тіркелмеген. Қазіргі уақытта 120 астам мемлекетте, екпелер күнтізбесіне пневмококты этиологиялы бактериялық менингит аурушаңдылықты төмендетудің тиімді әдісі болып табылатын пневмококты конъюгирленген вакцина енгізілген. Бұл мақалада ПКВ13 вакцинациясын қолдану жоспарында вакцинаның тиімділігі мен пневмококты менингитпен ауырған балалардың бактериальды менингитпен ауыру қауіпі сипатталған.

Негізгі сөздер: пневмококты менингит, вакцинация, ПКВ13, балалар

ВАКЦИНАЛЬНЫЙ СТАТУС (ПКВ13) ДЕТЕЙ С ПНЕВМОКОККОВЫМ МЕНИНГИТОМ

Сейдуллаева А., ${ }^{1,2}$ Баешева Д..,2, Турдалина Б., ${ }^{1,2}$, Алтынбекова А., ${ }^{1,2}$, Омарова А..$^{1,2}$, Хамитова М..$^{1,2}$, Ташенов С. ${ }^{1,2}$, Отарбаева А.,2, Кожахметов $\mathrm{C}^{3}$

${ }^{1}$ Кафедра детских инфекционных болезней, Медицинский университет Астана, город Нур-Султан, Республика Казахстан

${ }^{2}$ Кафедра детских инфекционных болезней, Многопрофильная городская детская больница №3, город Нур-Султан, Республика Казахстан

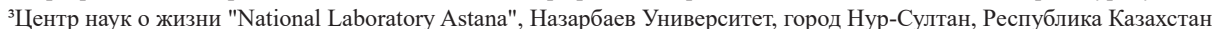

\section{PЕЗЮМЕ}

Пневмококковые менингиты у детей - это одна из причин развития серьезных неврологических осложнений. По данным различных авторов, в развитых странах частота заболеваемости колеблется от 8 до 34 случаев на 100000 населения, в Казахстане этиологическая расшифровка бактериальных менингитов отсутствует, в связи с этим официальных статистических данных об уровне заболеваемости инвазивными пневмококковыми заболеваниями не имеется. На сегодняшний день более чем в 120 странах в календари прививок внесена пневмококковая конъюгированная вакцина, которая является наиболее эффективным методом для снижения заболеваемости бактериальным менингитом пневмококковой этиологии. В данной статье отражена эффективность вакцинации и риск заболеваемости бактериальными менингитами у детей с пневмококковым менингитом в плане применения вакцины ПКВ13.

Ключевые слова: пневмококковый менингит, вакцинация, ПВК13, дети 


\section{Introduction}

According to the WHO estimates, 1.6 million people die every year from invasive pneumococcal diseases (IPD), of which 0.7-1 million are children under the age of 5 years $[1,2]$. Pneumococcal meningitis (PM) is one of the reasons for the development of serious neurological complications [3]. The incidence rate of pneumococcal infection among children in the Asia-Pacific region for 1999-2010 was 100-200 cases per 100,000 children under the age of two years [4], and in developed countries, the incidence rate ranges from 8 to 34 cases per 100,000 population [5]. In Kazakhstan, there is no etiological interpretation of bacterial meningitis (BM); therefore, there are no official statistics on the incidence of IPD.

Currently, pneumococcal conjugate vaccine (PCV7, PCV10 and PCV13), as recommended by the WHO, has been included in the national vaccination calendars for children in more than 120 countries [6]. The incidence of adult pneumococcal infections has decreased as a result of the population effect of PCV, which has become widely used among children [7]. In the national calendar of vaccinations of the Republic of Kazakhstan, vaccination against hemophilic infection (Hib) and pneumococcus (PCV13) is used for children from 2 to $15-18$ months.

The aim of this study was to evaluate the effectiveness of vaccination and the risk of the incidence of BM in children with PM in terms of the use of PCV13 (full dose, incomplete dose, and those not receiving the vaccine).

\section{Material and methods}

This study was conducted as part of the scientific project "Development of early diagnosis and preventive measures of hearing impairment after bacterial meningitis in children" AR05135091, implemented by grant funding for 2018-2020 on the basis of the Department of Pediatric Infectious Diseases, Nonprofit Joint Stock Company "Astana Medical University".
The patients included in the study were recruited in the Intensive Care Unit, infectious ward No 1 and 2 of the Multidisciplinary city children's hospital No 3 (MCCH No 3 ) of the akimat of NurSultan city. All patients underwent a comprehensive clinical, laboratory and instrumental study to establish a diagnosis. The object of the study was children with a diagnosis of pneumococcal meningitis, aged 1 month up to 5 years $(n=23)$. We studied the vaccine status of children with PM in terms of the use of PCV13 (full dose, incomplete dose and complete absence of vaccination).

Isolation of $\mathrm{N}$. meningitidis and $\mathrm{S}$. pneumoniae cultures from BM patients, according to the instructions, in Nur-Sultan city for 2015-2018 was carried out in one of three options: in vitro on a beveled nutrient agar, in the «Amies» transport medium, or as a microbial suspension in sterile $0.9 \% \mathrm{NaCl}$. Isolation of pure culture was made in the bacteriological laboratory of $\mathrm{MCCH}$ No 3 in Nur-Sultan. Samples were taken using the eSWAB Collection Kit (Copan, Diagnostics, Italy) and delivered within 4-24 hours to a bacteriological laboratory for research. Patients' age, type of material, and antibiotic intake during the last 3 days prior to sampling was documented. The microbiome was determined by isolating the total bacterial liquor DNA (Zymo BIOMICS DNA Microprep Kit, D4301, ZYMO RESEARCH CORP). $250 \mu$ of the sample was added to Lysis Tubes and $750 \mu 1$ of ZymoBIOMICS TM Lysis Solution was added [8].

Qualitative and quantitative indicators of the isolated DNA were determined using agarose gel electrophoresis and a Nanodrop ND2000 instrument (Thermofisher).

\section{Results and discussion}

In Table 1 it is presented that only $17.4 \%(n=4)$ of children with PM $(n=23)$ received the full dose of the pneumococcal vaccine. Two of them showed non-compliance with the interval between vaccination courses (Table 1).

\section{Table 1 Vaccine status in children with PM for 2015-2018}

\begin{tabular}{|l|l|l|l|l|}
\hline \multirow{2}{*}{ Vaccine name } & \multicolumn{2}{|l|}{ Vaccine status PM $(\mathrm{n}=23)$} & \multicolumn{2}{l|}{ incomplete dose } \\
\cline { 2 - 5 } & full dose & at large intervals & & \\
\cline { 2 - 5 } & according to schedule & $2(8,7)$ & $12(52,1)$ & $7(30,5)$ \\
\hline Anti-pneumococcal vaccine & $2(8,7)$ & & \\
\hline
\end{tabular}

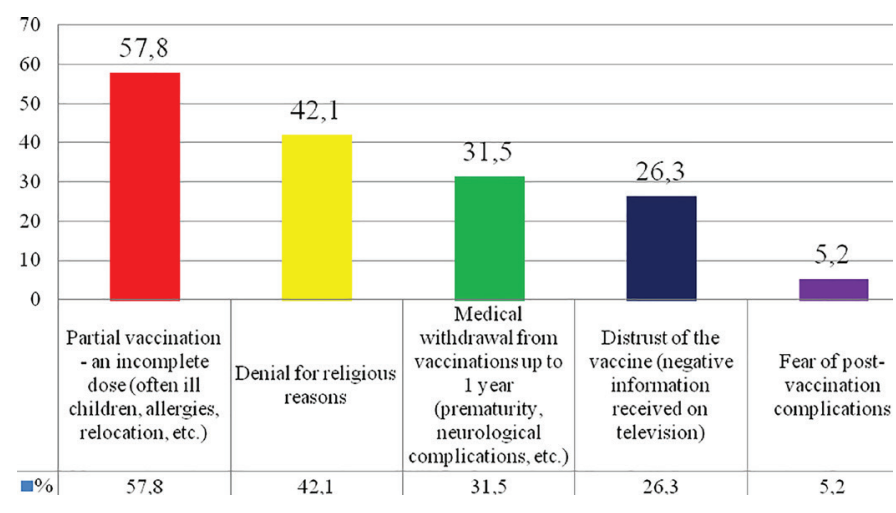

Figure 1 - Reasons for refusing vaccination with PCV 13 in patients with PM
In addition, there were such reasons as an incomplete dose - 52.1\% ( $\mathrm{n}=12)$, lack of vaccination - 30.5\% ( $\mathrm{n}=7)$, parental refusal to vaccinate - $30.5 \%(\mathrm{n}=7)$ and medical allotment $34.8 \%(\mathrm{n}=8)$ (Figure 1$)$.

The reasons for the incompleteness of the course and the non-receipt of the anti-pneumococcal vaccine in children with PM are: allergic manifestations, frequent acute respiratory infections and relocations, which is $57.8 \%$; religious denial of vaccination is observed in $42.1 \%$ of patients, medical rejection of vaccinations in children under 1 year of age (prematurity, neurological complications, etc.) $-31.5 \%$, distrust of the vaccine (negative information received from the media and social networks ) $-26.3 \%$; refusal of vaccinations due to fear of postvaccination complications was recorded in $5.2 \%$ of patients.

According to a meta-analysis by Kai Duan, Jin Guoand Ping Lei, premature babies have a high tolerance to PCV 7, PCV 10 or PCV 13. Despite the difference in the content of antigen 
and carrier protein in PCV, vaccinations of PCV 7, PCV10 or PCV13 can cause optimal immune response after vaccination in preterm infants with low and very low birth weight $[7,9]$. In our case, $31.5 \%$ of children with PM were born prematurely, which initially determined an increased risk of developing the disease, although timely vaccination from 2 months of life could serve as a factor in reducing the risk of IPD.

To assess the relationship between clinical indicators and vaccine status (not receiving the vaccine and not receiving the full dose of the vaccine) in children with PM, a Spearman correlation analysis was performed. A strong positive relationship was noted between the following indicators: between the severity (severe course) and the absence of vaccination $(r=0.9 ; p \leq 0.001)$, between the severity (severe course) and the incomplete dose of vaccination $(\mathrm{r}=0.7 ; \mathrm{p} \leq 0.05)$, prolonged temperature and lack of vaccination $(\mathrm{r}=0.9 ; \mathrm{p} \leq 0.001)$, neurological complications and lack of vaccination $(\mathrm{r}=0.8 ; \mathrm{p} \leq 0.001)$, number of hospital days (from 30 to 61 days) and the lack of vaccination ( $\mathrm{r}=0.9$; $\mathrm{p} \leq 0.001)$, combined antibacterial therapy and the absence of vaccination $(\mathrm{r}=0.8 ; \mathrm{p} \leq 0.001)$ (Table 2$)$.

Table 2 The relationship between the clinical course of PM and vaccine status

\begin{tabular}{|c|c|c|}
\hline \multicolumn{2}{|l|}{ Indicators } & \multirow{2}{*}{$\begin{array}{l}\text { The strength of the connection, and } \mathrm{P} * \\
\text { ПМ }\end{array}$} \\
\hline 1 clinical course & 2 vaccination status & \\
\hline \multirow[t]{2}{*}{ Severity (severe course) } & not receiving the vaccine & $0,9^{* *}$ \\
\hline & incomplete dose & $0,7^{*}$ \\
\hline \multirow[t]{2}{*}{ Long temperature } & not receiving the vaccine & $0,9 * *$ \\
\hline & incomplete dose & $0,6^{*}$ \\
\hline \multirow[t]{2}{*}{ Neurological complications } & not receiving the vaccine & $0,8^{*}$ \\
\hline & incomplete dose & $0,5^{*}$ \\
\hline \multirow[t]{2}{*}{ The number of bed days (from 30 to 61 days) } & not receiving the vaccine & $0,9^{* *}$ \\
\hline & incomplete dose & $0,6^{*}$ \\
\hline \multirow[t]{2}{*}{ Combined antibiotic therapy } & not receiving the vaccine & $0,8^{* *}$ \\
\hline & incomplete dose & $0,5^{*}$ \\
\hline $\begin{array}{l}* \mathrm{p} \leq 001 \\
* * \mathrm{p} \leq 0,05\end{array}$ & & \\
\hline
\end{tabular}

An average positive relationship was found between the duration of the temperature and the non-receipt of the full dose of vaccination $(r=0.6 ; p \leq 0.05)$, neurological complications and the receipt of an incomplete dose of the vaccine $(\mathrm{r}=0.5 ; \mathrm{p} \leq 0.05)$, the number of patients-days (from 30 to 61 days) and receiving an incomplete dose of the vaccine $(r=0.6 ; \mathrm{p} \leq 0.05)$, combined antibacterial therapy and receiving an incomplete dose of the vaccine $(r=0.5 ; \mathrm{p} \leq 0.05)$.

Subsequently, the effect of vaccination on cerebrospinal fluid microbiome was determined. A change in the cerebrospinal fluid microbiome was revealed in the group receiving vaccination and without vaccination (Figure 2).

The cerebrospinal fluid microbiome differs between the
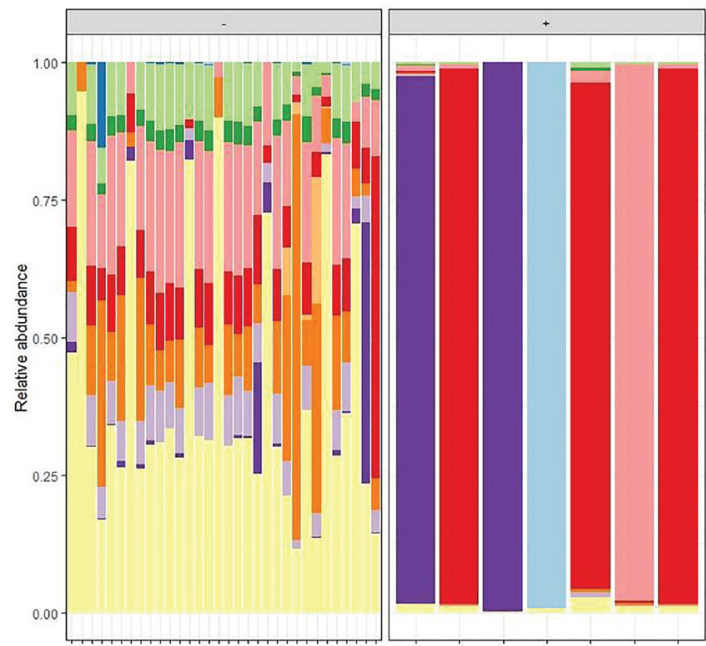

Figure 2

A clear separation of vaccinated and non-vaccinated groups is also shown using the Bray-Curtis and UniFrac methods (Figure 4). vaccinated and unvaccinated groups. In the unvaccinated group, streptococci are the predominant flora, while in the vaccinated group Staphylococcus, Neisseria, Haemophilus (Figure 3). The biodiversity of the microbial flora in the unvaccinated group is significantly different.

The Shannon index shows a significant difference in the biodiversity of cerebrospinal fluid microbiomes selected from patients with bacterial meningitis of an unconfirmed etiology. Shows the difference between vaccinated and unvaccinated groups. In the vaccinated group, bacteria belonging to the genera prevail: Neisseria, Haemophilus, Staphylococcus, while in the vaccinated group Streptococcus, Rothia, Granulicatella, Gemella, but also Haemophilus, Neisseria.

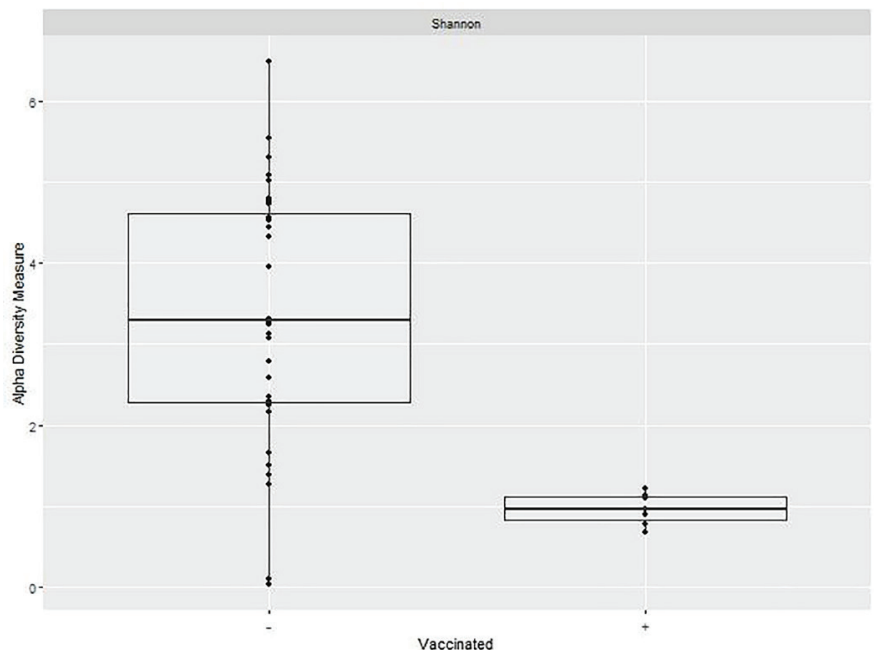

Figure 3

According to the distribution of microorganisms that make up the cerebrospinal fluid in patients with bacterial meningitis of unknown etiology, a clear distinction is made into two clusters. 


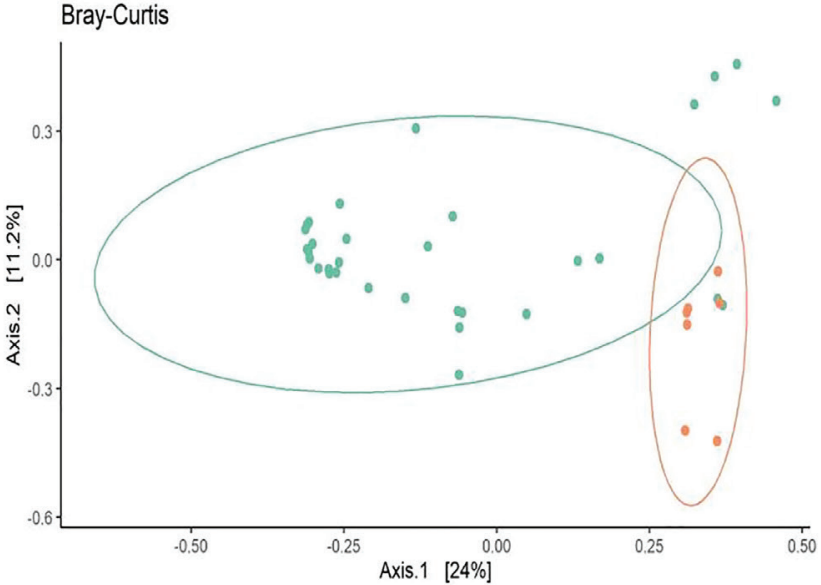

Figure 4

\section{Conclusion}

According to the national vaccination calendar of the Republic of Kazakhstan, it is necessary to vaccinate against vaccine-preventable infections that cause bacterial meningitis -

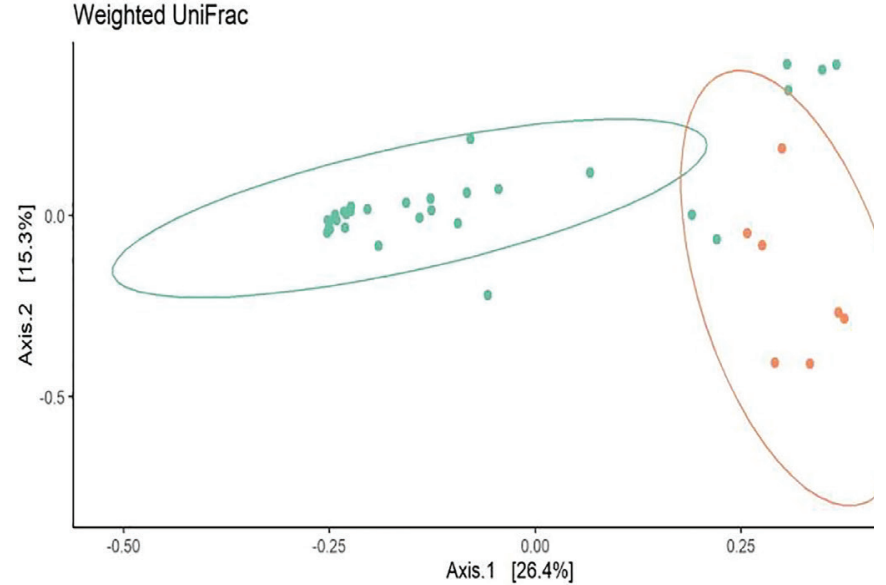

Hib, S. pneumoniae and N. meningitidis for all children from 2 months, including premature.

Disclosures: There is no conflict of interest for all authors.

\section{References}

1. Isaacman D.J., McIntosh Ed Fau-Reinert R.R., Reinert R.R. Burden of invasive pneumococcal disease and serotype distribution among Streptococcus pneumoniae isolates in young children in Europe: impact of the 7-valent pneumococcal conjugate vaccine and considerations for future conjugate vaccines. Int J Infect Dis. 2010; 14:197-209. https://doi.org/10.1016/j.ijid.2009.05.010

2. Juergens C., Trammel J., Shoji Y. et al. Late onset of injection site reactions after vaccination with the 13-valent pneumococcal conjugate vaccine in adult study populations. Hum Vaccin Immunother. 2018; 14(8):1948-1956. https://doi.org/10.1080/21645515.2018.1452576

3. Li Y.A., Tsang R., Desai S., Deehan H. Enhanced surveillance of invasive meningococcal disease in Canada, 2006-2011. Canada communicable disease report. 2014; 40(9):160-169. https://doi.org/10.14745/ccdr.v40i09a01

4. Van Opijnen T., Lazinski D.W., Camilli A. Genome-Wide Fitness and Genetic Interactions Determined by Tn-seq, a High-Throughput Massively Parallel Sequencing Method for Microorganisms. Curr Protoc Mol Biol. 2014; 16:1-24. https://doi.org/10.1002/0471142727. mb0716s106

5. van de Vooren K., Duranti S., Curto A., Garattini L. Cost Effectiveness of the New Pneumococcal Vaccines: A Systematic Review of European Studies. Pharmaco Economics. 2014; 32:29-45. https://doi.org/10.1007/s40273-013-0113-y

6. Balsells E., Guillot L., Nair H., Kyaw M.H. Kyaw Serotype distribution of Streptococcus pneumoniae causing invasive disease in children in the post-PCV era: A systematic review and meta-analysis. PLoS One. 2017; 12(5):1-20. https://doi.org/10.1371/journal. pone. 0177113

7. Duan K., Guo J., Lei P. Safety and Immunogenicity of Pneumococcal Conjugate Vaccine in Preterm Infants: A Meta-Analysis. Indian J Pediatr. 2017; 84:101-110. https://doi.org/10.1007/s12098-016-2248-2

8. Chen S., Zhou Y., Chen Y., Gu J. fastp: an ultra-fast all-in-one FASTQ preprocessor. Bioinformatics. 2018; 34(17):i884-i890. https:// doi.org/10.1093/bioinformatics/bty560

9. Szynczewska E., Chlebna-Sokół D. Immunogenicity of heptavalent conjugate vaccine against Streptococcus Pneumoniae in premature babies with low birth weight. PediatrNeonatol. 2014; 55:101-117. https://doi.org/10.1016/j.pedneo.2013.06.005

How to cite this article: Aliya Seidullayeva, Dinagul Bayesheva, Bayan Turdalina, Alyona Altynbekova, Aliya Omarova, Meruert Khamitova, Sabit Tashenov, Aislu Otarbayeva, Samat Kozhakhmetov. Vaccination status (PCV13) of children with pneumococcal meningitis. J Clin Med Kaz. 2020; 1(56):46-49 